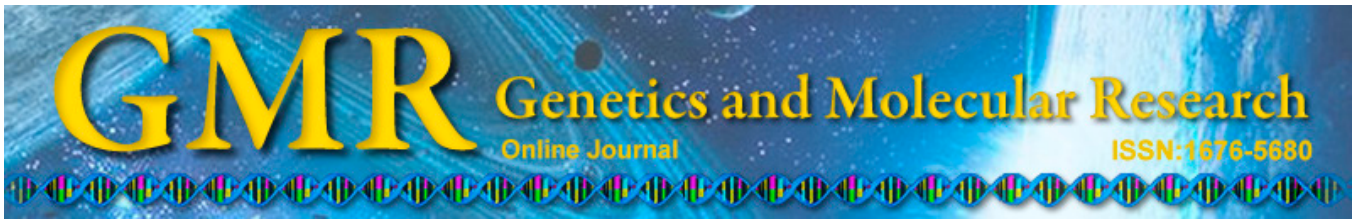

\title{
Molecular identification of phosphate- solubilizing native bacteria isolated from the rhizosphere of Prosopis glandulosa in Mexicali valley
}

\author{
L. Moreno-Ramírez, D. González-Mendoza, C. Cecena-Duran and \\ O. Grimaldo-Juarez
}

Instituto de Ciencias Agrícolas, Universidad Autónoma de Baja California, Baja California, México

Corresponding author: D. González-Mendoza

E-mail: daniasaf@gmail.com

Genet. Mol. Res. 14 (1): 2793-2798 (2015)

Received February 28, 2014

Accepted July 14, 2014

Published March 31, 2015

DOI http://dx.doi.org/10.4238/2015.March.31.9

\begin{abstract}
One of the main limitations in intensive crop production in Northwestern Mexico is the dependence on the use of phosphate fertilizer. In this study, we isolated indigenous microorganisms with phosphate solubilization capacities from mesquite (Prosopis glandulosa) present in the Mexicali valley. In total, 4 bacteria were isolated from the rhizosphere of mesquite, including ICA01, ICA02Ba, ICA03Bs, and ICA04Ma. The bacterial isolates were identified based on their phenotypic and 16S rRNA gene sequencing data to be Acinetobacter calcoaceticus. The results showed that ICA01 was the most efficient in solubilizing phosphate, followed by ICA02Ba and ICA03Bs, while ICA04Ma showed the lowest phosphate-solubilizing activity. The $\mathrm{pH}$ value of the culture medium decreased with bacterial growth, suggesting that these strains produce organic acids that solubilize phosphorus. These results will be useful for biotechnological studies and A. calcoaceticus may be
\end{abstract}


employed for biofertilization programs in northwest Mexico.

Key words: DNA; Mexicali valley; Mesquite; Microorganism; Phosphorous

\section{INTRODUCTION}

The Mexicali valley is a semi-arid environment that is an important agricultural region in northwest Mexico. However, a main limitation in intensive crop production in this valley is the dependence on the use of phosphate fertilizer and the water-rich in salts used in irrigation of crops. These substances negatively affect nutrient absorption [e.g., phosphorus (P)] by plants (Munns any Tester, 2008). P is an essential nutrient used to build cell molecules such as phospholipids and nucleic acids and is involved in energy transformation (ATP). In the soil, a very small fraction of $\mathrm{P}$ exists in solution because of its very high reactivity. As a result, $\mathrm{P}$ deficiency is a widespread problem and $\mathrm{P}$ fertilizers are almost universally required to maintain crop production (Turan et al., 2006). However, the efficiency of applied P rarely exceeds $30 \%$ because of the varying chemical reactions that occur in the presence of salts, limiting the availability of this nutrient (fixation in the form of calcium phosphate) for plants, particularly in arid and semi-arid areas (Evelin et al., 2009; Srinivasan et al., 2012). The use of rhizospheric microorganisms represents an option economically and environmentally friendly to enhance solubilization of phosphate in this arid and semi-arid area and to provide sufficient quantities of $\mathrm{P}$ for plant nutrition. P-solubilizing microorganisms can solubilize and mineralize P from inorganic and organic pools of total soil $\mathrm{P}$, and may be used as inoculants to increase the availability of P to plants (Richardson, 2001). Indigenous microorganisms capable of phosphorus solubilization show superior adaptability to the environment compared to the introduced strains. Thus, indigenous strains may perform better than introduced strains in promoting crop growth because of their superior adaptability to the environment (Abbas et al., 2007).

In Mexico, the study of indigenous microorganisms capable of phosphorus solubilization has focused on isolating microorganisms from mangroves (Avicennia germminans), crops (e.g., Zea mays), and cardon (Pachycereus pringlei) (Vazquez et al., 2000; Espinosa-Victoria et al., 2009; Bashan et al., 2009). However, studies examining the diversity of indigenous microorganisms in extreme environments in Baja California, mainly Mexicali valley, are scarce. Therefore, we isolated indigenous microorganisms with phosphate-solubilization capacities from the rhizospere of the mesquite tree (Prosopis glandulosa) in the Mexicali valley.

\section{MATERIAL AND METHODS}

\section{Field collection of rhizosphere soil}

Mesquite rhizosphere samples were collected from a native population in the Mexicali valley ( $\left.32^{\circ} 24^{\prime} 6.8394^{\prime \prime} \mathrm{N}, 115^{\circ} 11^{\prime} 51^{\prime \prime} \mathrm{O}\right)$, Baja California, México. Approximately $100 \mathrm{~g}$ soil adhering to the roots of $P$. glandulosa was collected in sterilized plastic bags and transported to the laboratory at room temperature for isolation of phosphate-solubilizing bacteria. 


\section{Isolation and screening of P-solubilizing bacteria}

One-gram samples of rhizospere soil were added to $9.0 \mathrm{~mL}$ sterile distilled water in a $10-\mathrm{mL}$ centrifuge tube and shaken for $10 \mathrm{~s}$. Next, $1 \mathrm{~mL}$ soil suspension was transferred to another centrifuge tube containing $9 \mathrm{~mL}$ sterilized distilled water using a sterilized pipette to prepare a 1:100 dilution, and $1 \mathrm{~mL}$ suspension was again transferred to another tube containing $9 \mathrm{~mL}$ sterilized distilled water (1:1000 dilution). For the isolation of phosphate-solubilizing bacteria; $0.2-\mathrm{mL}$ serial dilutions were spread on Pikovskaya's (PVK) agar and rotated gently to disperse the suspension uniformly.

Three replicates were maintained for each sample. Tricalcium phosphate as the sole phosphate source and bromophenol blue as a $\mathrm{pH}$ indicator dye, $\mathrm{pH}$ 6.8-7.0, were used in the $\mathrm{PVK}$ formulation. The Petri dishes were incubated at $30^{\circ} \mathrm{C}$ for 7 days and colonies with a clear halo were marked as positive for phosphate solubilization and stored for future analysis.

\section{Molecular identification of bacterial isolates}

Total DNA from 4 native phosphate-solubilizing microbes (ICA01, ICA02Ba, ICA03Bs, and ICA04Ma) was extracted based on the method of Mendez-Trujillo et al. (2013). The DNA from the 4 strains was amplified by polymerase chain reaction (PCR) with Taq DNA polymerase according to manufacturer instructions (Invitrogen, Carlsbad, CA, USA). PCR analysis was performed using $2 \mu \mathrm{L}$ DNA (20 ng) as the template. PCRs included the 16S rRNA gene with universal primers 27 forward (AGA GTT TGA TCC TGG CTC AG) and 27 reverse (AAG GAG GTG ATC CAG CCG CA). The PCRs were carried out using the following protocol: $94^{\circ} \mathrm{C}$ for 5 $\min (1 \mathrm{cycle}), 54^{\circ} \mathrm{C}$ for $40 \mathrm{~s}$, and $72^{\circ} \mathrm{C}$ for $1 \mathrm{~min}(30$ cycles). The quality of the PCRs analyzed on a $1 \%$ Tris acetate EDTA agarose gel, and bands were visualized by staining with ethidium bromide. Images were acquired and stored using the Multidoc-It Digital Imaging system (UVP, Upland, CA, USA). The PCR products were purified using "Purelink ${ }^{\circledR}$ PCR Purification" kit (Invitrogen) and sequencing was carried out using an ABI Prism 377 DNA sequencer (Applied Biosystems, Foster City, CA, USA). Nucleotide sequence data were analyzed in GenBank data with the BLASTn (Altschul et al., 1997).

\section{Phosphate solubilization index}

Bacterial isolates (ICA01, ICA02Ba, ICA03Bs, and ICA04Ma) were selected from the colonies based on their ability to form a clear halo on PVK agar. The isolates were aseptically spot-inoculated onto the center of an agar plate. All plates were incubated at $28^{\circ} \pm 2^{\circ} \mathrm{C}$ for 7 days. A clear zone around a growing colony indicated phosphate solubilization and was measured as the phosphate solubilization index (SI). The phosphate SI was evaluated using the following formula (Edi-Premono et al., 1996):

Solubilizing index $=[($ colony diameter + halo zone diameter $) /$ colony diameter $]$

\section{Statistical analysis}

The data obtained in the present study are the average of at least 3 replicates per treatment and are reported as means \pm standard deviation. 


\section{RESULTS AND DISCUSSION}

In the present study, phylogenetic analysis of $16 \mathrm{~S}$ rRNA genes revealed that the ICA01, ICA02Ba, ICA03Bs, and ICA04Ma strains formed a stable clade with the members of the genus of Acinetobacter spp, showing sequence similarity of $99 \%$ for the $16 \mathrm{~S}$ rRNA gene. The neighbor-joining method was employed to construct a phylogenetic tree to illustrate the relationships between the 16S rRNA strain sequences and those of other Acinetobacter species (Figure 1). Thus, the 4 strains were designated as Acinetobacter calcoaceticus or Acinetobacter spp, and their sequences were deposited in GenBank with accession numbers KJ190162 (ICA01 or Mc), KJ190163 (ICA02Ba), KJ190164 (ICA03Bs), and KJ190165 (ICA04Ma). The phosphate solubilization potential of these strains was observed over a period of 7 days on PVK agar media (Table 1).

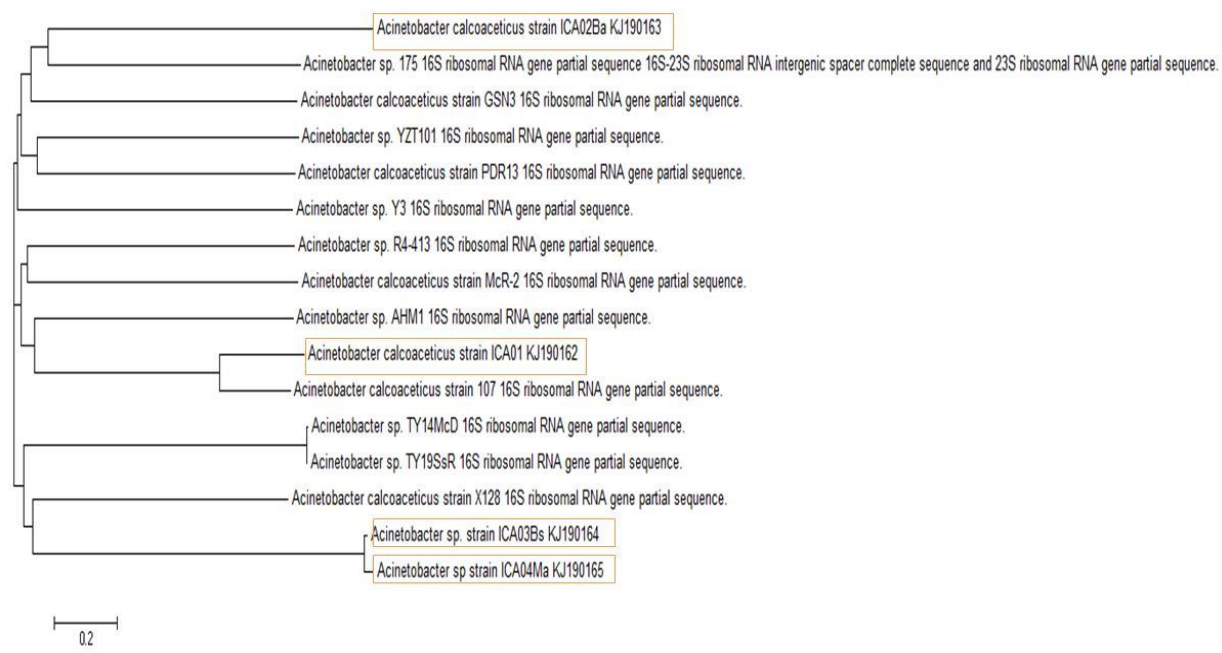

Figure 1. Phylogenetic tree based on 16S rRNA gene sequences, constructed using the neighbor-joining method, showing close relationship between the 4 strains and the nearest relatives of the genus Acinetobacter. Numbers at nodes indicate percentages of occurrence in 1000 bootstrapped trees; only values greater than $90 \%$ are shown.

Table 1. Solubilization index of bacteria isolated from the rhizosphere of Prosopis glandulosa after 7 days of incubation.

\begin{tabular}{lc}
\hline Strain & Solubilization index \\
\hline ICA01 & $4.37 \pm 0.040$ \\
ICA02Ba & $3.90 \pm 0.157$ \\
ICA03Bs & $3.84 \pm 0.138$ \\
ICA04Ma & $3.40 \pm 0.035$ \\
\hline
\end{tabular}

Values are reported as means + standard deviation of 3 independent replicates.

The results showed that ICA01 was the most efficient phosphate solubilizer with an SI value of 4.40, followed by the ICA02Ba and ICA03Bs with SI values of 3.90 and 3.84, respectively; ICA04Ma showed the lowest SI value of 3.40. The increase in the clearing zone on PVK agar media over time suggested increased acid secretion and thus conversion of insoluble phosphate to a soluble form (Figure 2). 

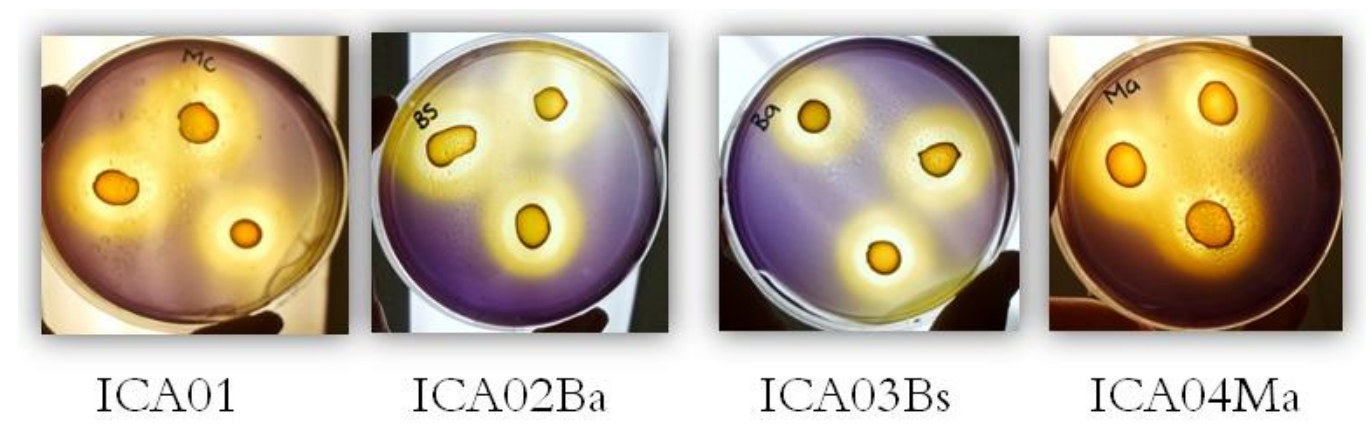

Figure 2. Acinetobacter calcoaceticus strain colonies exhibiting halozone of $\mathrm{P}$ solubilization and decreased $\mathrm{pH}$.

Thus, the phosphate solubilization potential observed in the 4 strains may be attributed to the ability of these microorganisms to reduce the surrounding $\mathrm{pH}$ by releasing either organic acids or protons (Hariprasad and Niranjana, 2009; Charana and Yoon, 2013). Reports of Acinetobacter spp and their phosphate-solubilizing activity are limited. However, Peix et al. (2009) and Kang et al. (2009) suggested that Acinetobacter species that decrease the medium $\mathrm{pH}$ during growth are efficient P solubilizers. Studies of the rhizoplane of Oryza sativa L. by Islam et al. (2007) showed that 2 strains of Acinetobacter spp had higher P-solubilizing activity followed by a drop in $\mathrm{pH}$, suggesting that Acinetobacter spp secrete organic acids to solubilize insoluble $\mathrm{P}$. These results will be useful information for biotechnological studies examining the use of Acinetobacter calcoaceticus for biofertilization programs.

\section{ACKNOWLEDGMENTS}

Research supported by the $17^{\mathrm{a}}$ Convocatoria Interna de Apoyo a Proyectos de Investigación de la Universidad Autónoma de Baja California (UABC) and CONACYT (\#313890).

\section{REFERENCES}

Abbas AG, Seyyed MA, Alikhani HA, Allahdadi I, et al. (2007). Isolation and selection of indigenous Azospirillum spp. and the IAA of superior strains effects on wheat roots. World J. Agric. Sci. 3: 523-529.

Altschul SF, Madden TL, Schäffer AA, Zhang J, et al. (1997). Gapped BLAST and PSI-BLAST: A new generation of protein database search programs. Nucleic Acids Res. 25: 3389-3402.

Bashan Y, Salazar B, Puente ME, Bacilio M, et al. (2009). Enhanced establishment and growth of giant cardon cactus in an eroded field in the Sonoran Desert using native legume trees as nurse plants aided by plant growth promoting microorganisms and compost. Biol. Fertil. Soils 45: 585-594

Charana WB and Yoon MH (2013). Isolation and characterization of phosphate solubilizing bacteria and their coinoculation efficiency on tomato plant growth and phosphorous uptake. Afr. J. Microbiol. Res. 3: 266-275.

Edi-Premono M, Moawad AM and Vlek PLG (1996). Effect of phosphate-solubilizing Pseudomonas putida on the growth of maize and its survival in the rhizosphere. Indones. J. Crop Sci. 11: 13-23.

Espinosa-Victoria D, López-Reyes L and De La Cruz-Benítez A (2009). Use of 16s rRNA gene for characterization of phosphate-solubilizing bacteria associated with corn. Rev. Fitotec. Mex. 32: 31-37

Evelin H, Kapoor R and Giri B (2009). Arbuscular mycorrhizal fungi in alleviation of salt stress: a review. Ann. Bot. 104: 1263-1280. 
Hariprasad P and Niranjana SR (2009). Isolation and characterization of phosphate solubilizing rhizobacteria to improve plant health of tomato. Plant Soil 316: 13-24.

Islam MT, Deora A, Hashidokoa Y, Rahmana A, et al. (2007). Isolation and identification of potential phosphate solubilizing bacteria from the rhizoplane of Oryza sativa L. cv. BR29 of Bangladesh. Z. Naturforsch. 62c: 103-110

Kang SM, Joo GJ, Hamayun M, Na CI, et al. (2009). Gibberellin production and phosphate solubilization by newly isolated strain of Acinetobacter calcoaceticus and its effect on plant growth. Biotechnol. Lett. 31: 277-281.

Mendez-Trujillo V, Moreno-Ramírez L, Carrillo-Beltran M and González-Mendoza D (2013). Fast protocol for DNA isolation of DNA from bacterial isolated from a hyper-arid environment. J. Pure Appl. Microbiol. 7: 2713-2716.

Munns R and Tester M (2008). Mechanisms of salinity tolerance. Annu. Rev. Plant Biol. 59: 651-681.

Peix A, Lang E, Verbarg S, Spröer C, et al. (2009). Acinetobacter strains IH9 and OCI1, two rhizospheric phosphate solubilizing isolates able to promote plant growth, constitute a new genomovar of Acinetobacter calcoaceticus. Syst. Appl. Microbiol. 32: 334-341.

Richardson AE (2001). Prospects for using soil microorganisms to improve the acquisition of phosphorus by plants. Aust. J. Plant Physiol. 28: 897-906

Srinivasan R, Alagawadi AR, Yandigeri MS, Meena KK, et al. (2012). Characterization of phosphate-solubilizing microorganisms from salt-affected soils of India and their effect on growth of sorghum plants [Sorghum bicolor (L.) Moench]. Ann. Microbiol. 62: 93-105.

Turan M, Ataoğlu N and Şahın F (2006). Evaluation of the capacity of phosphate solubilizing bacteria and fungi on different forms of phosphorus in liquid culture. J. Sus. Agric. 28: 99-108.

Vazquez P, Holguin G, Puente ME, Lopez-Cortes A, et al. (2000). Phosphate-solubilizing microorganisms associated with the rhizosphere of mangroves in a semiarid coastal lagoon. Biol. Fertil. Soils 30: 460-468. 